\title{
技術報告
}

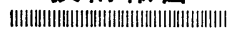

\section{小児科領域における遊離トリョードサイロニン測定の検討 ${ }^{\dagger}$}

\author{
池上 宏‡, 猪股弘明, 田丸清恵, 佐々木 望, 新美仁男, 中島博徳 \\ 千葉大学医学部小児科 280 千葉市亥鼻 1-8-1 \\ 1984年 8 月 4 日 受理
}

Key Words: free triiodothyronine, radioimmunoassay, childhood

\section{1. 緒 言}

近年のラジオイムノアッセイ(RIA)の開発により, 容易に各種甲状腺ホルモンの測定が行われるようにな ったが，遊離トリヨードサイロニン（以下， $\mathrm{FT}_{3}$ ) は， 平衡透析法"ををはじめとして手技の煩雑さのために, ルーチンな検査として行われなかった。しかし,最近, $\mathrm{RIA}$ キット（アマレックス・フリー $\mathrm{T}_{3} \mathrm{RIA}$ キット） が開発され，簡便な測定が可能となった。今回，同キ ットの試用の機会が得られたので，基礎的拈よび小児 科領域における臨床的検討の結果について報告する。

\section{2. 測定原理および方法 (Table 1)}

トレーサとして抗 $\mathrm{T}_{3}$ 抗体に対しては $\mathrm{T}_{3}$ と同様の 親和性を有するが，サイロキシン結合グロブリン （TBG）に対する親和性はきわめて小さいという性質 をるつ ${ }^{125} \mathrm{I}-\mathrm{T}_{3}$ 誘導体 $\left({ }^{125} \mathrm{I}-\mathrm{T}_{3}-\mathrm{X}\right)$ を，抗体としては 微細プラスチック粒子上に固相化した抗 $\mathrm{T}_{3}$ 抗体を用 いている。被検血清にこの ${ }^{125} \mathrm{I}-\mathrm{T}_{3}-\mathrm{X}$ を加え, 抗 $\mathrm{T}_{3}$ 抗体に対して $\mathrm{FT}_{3}$ と競合させた後, 遠心分離し, 抗 $\mathrm{T}_{3}$ 抗体に結合した ${ }^{125} \mathrm{I}-\mathrm{T}_{3}-\mathrm{X}$ を沈殿させ，上清除去後， 沈殿物の放射能を測定し, 標準曲線から $\mathrm{FT}_{3}$ 濃度を読 みとる。

\footnotetext{
† Study of the Measurement of Free Triiodothyronine in the Domain of Department of Pediatrics. Hiroshi IKegami $\ddagger$, Hiroaki Inomata, Kiyoe TAMARU, Nozomu SASAKI, Hiroo Nirmi and Hironori NAKa JIMA: Department of Pediatrics, Chiba University School of Medicine, 1-8, Inohana 1-chome, Chiba-shi 280.

$\ddagger$ Present address: Chiba Shiritsu Kaihin Hospital, 1-31, Isobe 3-chome, Chiba-shi 260.
}

Table 1 Assay procedure

$100 \mu l$ standards and unknown serum

$500 \mu l l^{125} \mathrm{I}-\mathrm{T}_{3} \stackrel{\downarrow}{\text { derivative solution }}$

$500 \mu l$ Amerlex $\mathrm{T}_{3}$ antibody suspension

Vortex mix

Incubation at $37^{\circ} \mathrm{C}$ for 2 hours

$\downarrow$

Centrifuge for 15 minutes at $1500 \mathrm{~g}$

$\downarrow$

Discarding the supernatant liquids

Count

\section{3. 方法および対象}

基礎的検討として，インキュベーション時間掞よび 温度の変化による標準曲線の変動, アッセイ内・アッ セイ間 (within, between) の再現性について調べた。

臨床的検討として，小児の正常値，小児期甲状腺疾 患に找ける $\mathrm{FT}_{3}$ 值, 未熟児の $\mathrm{FT}_{3}$ 值, $\mathrm{FT}_{3}$ と total $\mathrm{T}_{3}$ (Autopak $\mathrm{T}_{3} \mathrm{RIA}$ ), $\mathrm{FT}_{3}$ と $\mathrm{FT}_{4}$ (アマレックスフ リー $\left.T_{4}\right)$ との相関について調べた。

対象は, euthyroid status にある1-15歳の小児 61 名, 乳児 8 名, TBG 欠損症 19 名, 甲状腺機能進症 7 名, 甲状腺機能低下症 5 名, 神経性食思不振症 5 名, インスリン依存性糖尿病 5 名, 低アルブミン血症 6 名（ネフローゼ症候群 5 名, タンパク漏出性胃腸症 1 名)，健康成人 10 名，未熟児 46 名である。

\section{4. 結 果}

\section{$4 \cdot 1$ 基礎的検討}

$4 \cdot 1 \cdot 1$ インキュベーション温度の影響 インキュベーション温度の標準曲線に及ぼす影響を 


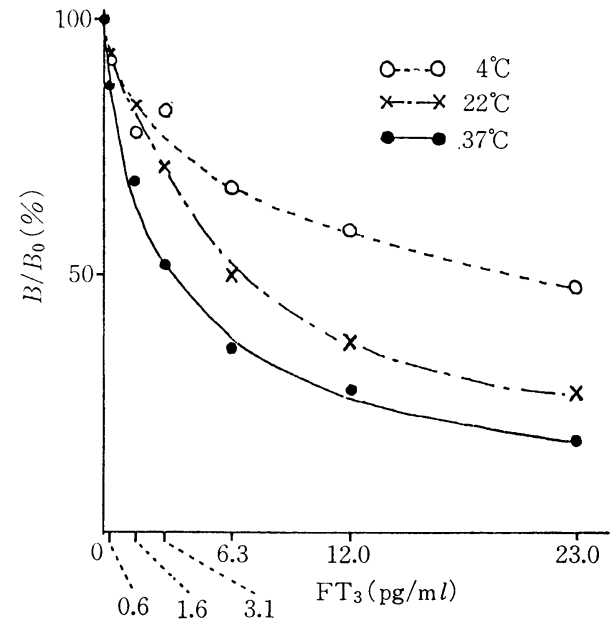

Fig. 1 Effect of incubation temperature.

みるため, $4^{\circ} \mathrm{C}, 22^{\circ} \mathrm{C}$ (室温), $37^{\circ} \mathrm{C}$ (指定温度) とし, 120 分間インキュベートしたさいの標準曲線を描いた (Fig. 1)。37Cで最も急峻なカーブが得られた。

$4 \cdot 1 \cdot 2$ インキュベーション時間の影響

インキュベーション時間の標準曲線に及ぼす影響を みるために，60分，120分 (指定時間)，180分としたさ いの標準曲線を描いた (Fig. 2)。120分と180分で同じ 良好なカーブが得られた。

\section{$4 \cdot 1 \cdot 3$ 再現性}

アッセイ内・アッセイ間 (within, between) におけ る再現性を調べた（Table 2)。おのおの良好な成績が 得られた。

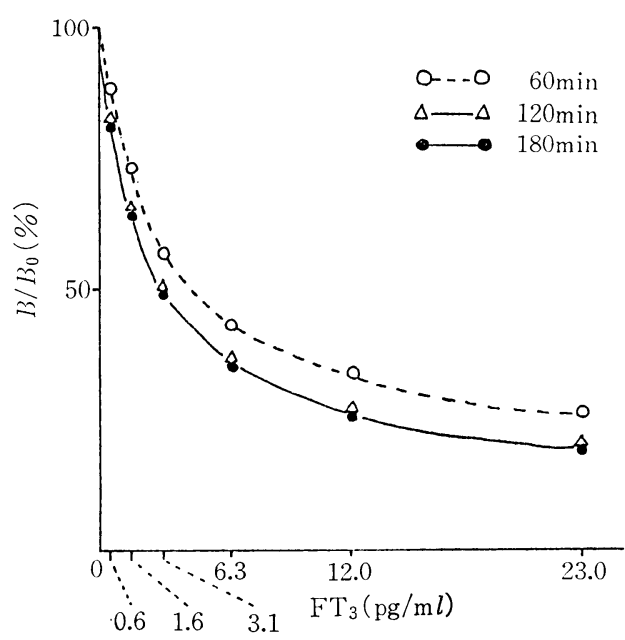

Fig. 2 Effect of incubation time.

\section{$4 \cdot 2$ 臨休的検討}

\section{$4 \cdot 2 \cdot 1$ 正常小児の $\mathrm{FT}_{3}$ 值}

Euthyroid status にある乳児および 1 - 15歳の小児の $\mathrm{FT}_{3}$ 值を調べた (Fig. 3)。乳児では， $5.3 \pm 0.7 \mathrm{pg} / \mathrm{ml}$ ， mean士2 S.D.は3.9-6.4 pg/mlであった。1-5 歳の小 児では $5.3 \pm 0.7 \mathrm{pg} / \mathrm{ml}, 6-10$ 歳では $4.8 \pm 0.7 \mathrm{pg} / \mathrm{ml}$, 11- 15 歳では $4.7 \pm 0.7 \mathrm{pg} / \mathrm{ml}$ で，1-15歳全体では, $5.0 \pm 0.7 \mathrm{pg} / \mathrm{ml}$, mean \pm 2 S.D. は3.6-7.1 pg/mlの範 囲となった。成人では，3.6士0.6 pg/ml であった。 $4 \cdot 2 \cdot 2$ 各疾患における $\mathrm{FT}_{3}$ 值 結果を Fig. 4 に示す。正常小巟の mean \pm 2 S.D. の
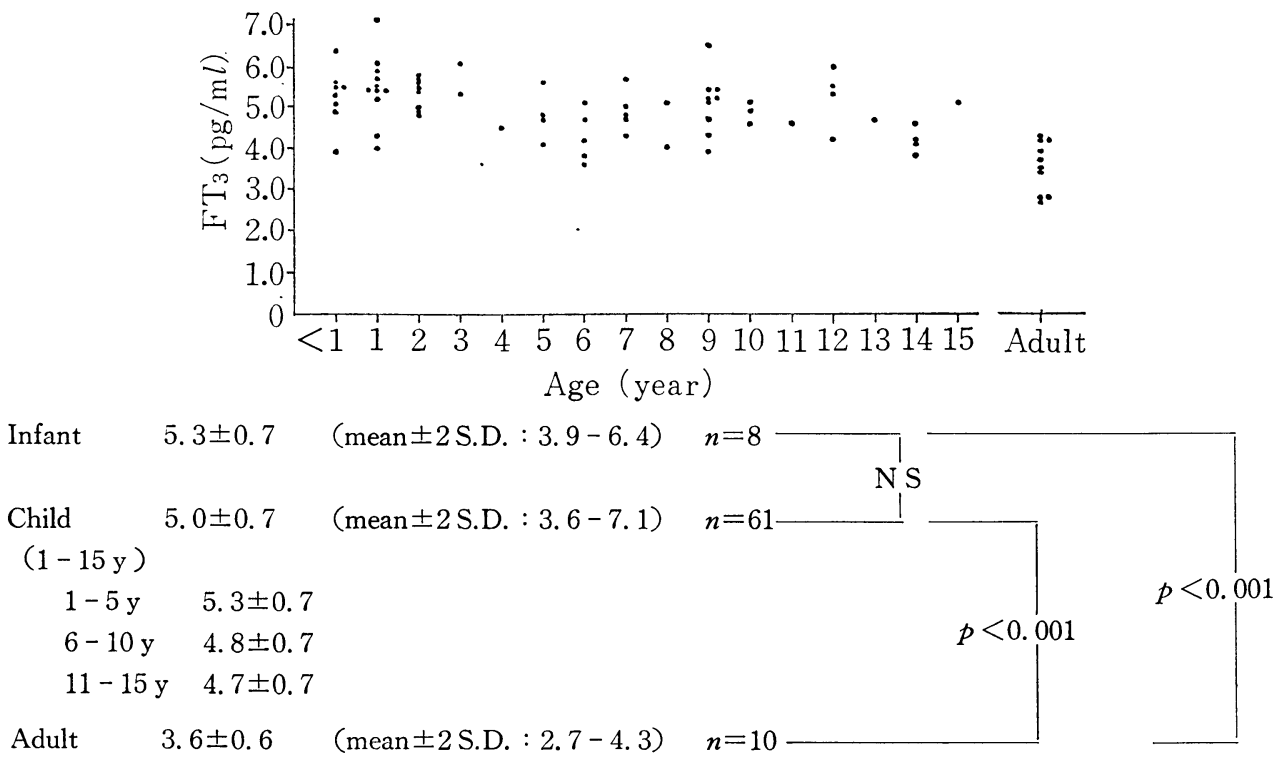

Fig. 3 Serum $\mathrm{FT}_{3}$ value of normal children. 
Table 2 Precision

Within assay

\begin{tabular}{lrrr}
\hline & 0.6 & 3.0 & 12.3 \\
& 0.5 & 3.0 & 14.6 \\
& 0.6 & 3.0 & 15.4 \\
& 0.5 & 2.9 & 11.9 \\
& 0.8 & 3.1 & 13.1 \\
& 0.5 & 2.8 & 14.4 \\
& 0.5 & 2.9 & 13.3 \\
& 0.6 & 2.8 & 14.7 \\
& 0.6 & 3.0 & 15.3 \\
Mean & 0.6 & 2.8 & 12.9 \\
S.D. & 0.6 & 2.9 & 13.8 \\
Between assay & 0.1 & 0.1 & 1.1 \\
& 16.7 & 3.4 & 8.6 \\
\hline & 1.3 & & \\
\hline Mean & 1.3 & 5.7 & 11.5 \\
C.D. & 1.5 & 6.1 & 12.0 \\
& 0.2 & 0.3 & 14.2 \\
& 13.3 & 4.9 & 9.0 \\
\hline
\end{tabular}

範囲を正常值としたところ，TBG 欠損症では，4.4士 $0.6 \mathrm{pg} / \mathrm{ml}$ で全例正常範囲内であった。甲状腺機能立 進症 7 名（scale over したものは除外した）は，13.2 $\pm 4.9 \mathrm{pg} / \mathrm{ml}$ で全例正常値より高値であった。甲状腺 機能低下症 5 名では $1.0 \pm 0.7 \mathrm{pg} / \mathrm{ml}$, 神経性食思不振 症 5 名では $1.9 \pm 0.9 \mathrm{pg} / \mathrm{ml}$, 低アルブミン血症 6 名で は1.2土0.6 pg/ml と全例正常範囲より低值であった。 糖尿病 5 名のうち 4 名は正常範囲にあったが，低值で あった 1 名はケトアシドーシスをくり返すュントロー ル不良の児であった。

$4 \cdot 2 \cdot 3 \mathrm{FT}_{4}$ との関係
関係を Fig. 5 に示す。 $r=0.96$ と良好な相関が得ら れた。

$4 \cdot 2 \cdot 4$ Total $\mathrm{T}_{3}$ 值々の関係

関係を Fig. 6 に示す。 $r=0.79$ と良好な相関が得ら れた。

$4 \cdot 2 \cdot 5$ 未熟児の $\mathrm{FT}_{3}$

出生後の週ごとの経時的変化を Fig. 7 に示す。生後 第 1 週では, 満期産児 $(n=6) 3.1 \pm 1.1 \mathrm{pg} / \mathrm{ml}$ に対し, 未熟児では, 出生体重 $1000-1499 \mathrm{~g}(n=2)$ で $0.8 \pm 0.3$ $\mathrm{pg} / \mathrm{ml}, 1500-1999 \mathrm{~g}(n=9)$ で1. $3 \pm 0.3 \mathrm{pg} / \mathrm{ml}, 2000$ $2499 \mathrm{~g}(n=1)$ で $1.3 \mathrm{pg} / \mathrm{ml}$ であり, きわめて低值であ る。しかし, 出生体重1500-2499 g の大きな群では, 次第に上昇してゆき, 生後 6 週では乳児の正常下限に はいる。1000-1499 g では依然として低值を続ける。

\section{5. 考察}

本キットによる $\mathrm{FT}_{3}$ 測定は, 再現性がよく安定した 測定值が得られること, total $\mathrm{T}_{3}$ や $\mathrm{FT}_{4}$ ともよく相関 し，甲状腺疾患に拈いて進症，低下症，正常者を明 確に分離できること，TBG 欠損症では全例正常範囲 にあり，測定原理からいっても TBG の変動が測定值 に影響を及ぼさないことなどから，小児科領域におい ても，有用な甲状腺機能検査の一つであるといえる。

しかし，今回測定した低アルブミン血症（ネフロー ゼ症候群, タンパク漏出性胃腸症)の症例では, $\mathrm{FT}_{3}$ が 甲状腺機能低下症の児と同じくらい低值で，これら症 例では甲状腺機能低下症を示すような TSH 高值がみ られないことから,はたして生体内では本当に $\mathrm{FT}_{3}$ が

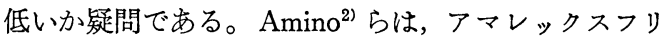
一 $\mathrm{T}_{4}$ でアルブミンが誘導体と抗体との結合を阻害す るため，低アルブミン血症ではFT $\mathrm{FT}_{4}$ が実際より低值に なると報告している。本キットにも同様の機序が働い ていることが示唆されるが，生理学的な面も含めて一

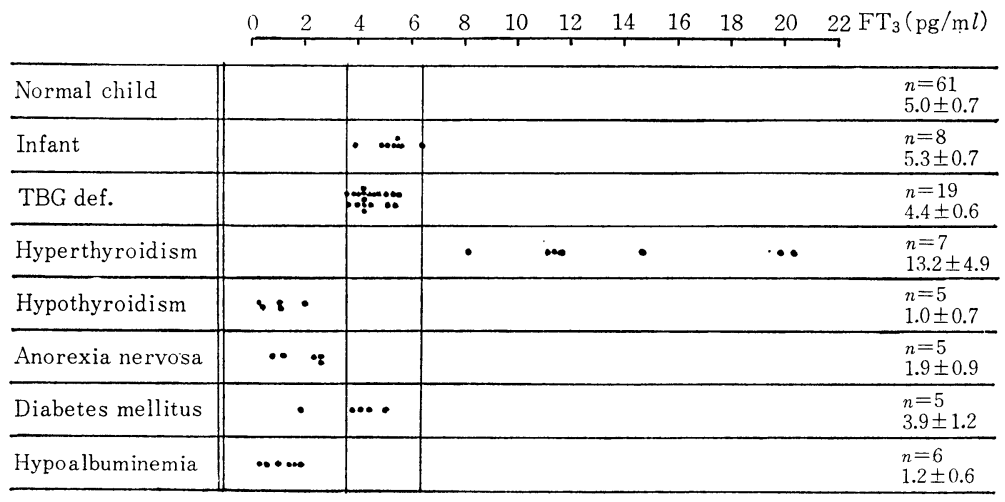

Fig. $4 \mathrm{FT}_{3}$ levels in various clinical states. 


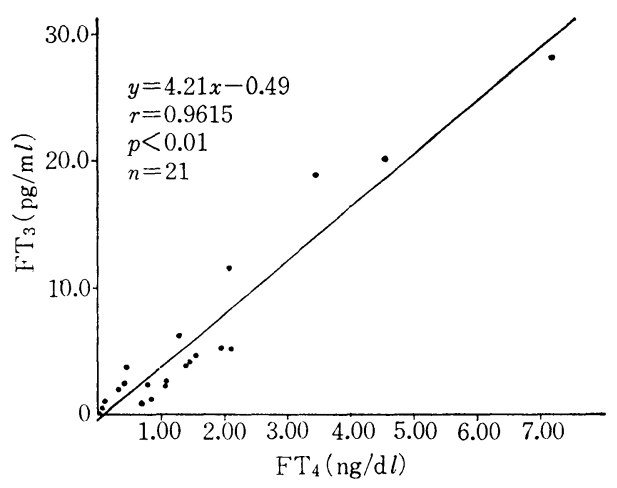

Fig. 5 Relation between $\mathrm{FT}_{3}$ and $\mathrm{FT}_{4}$.

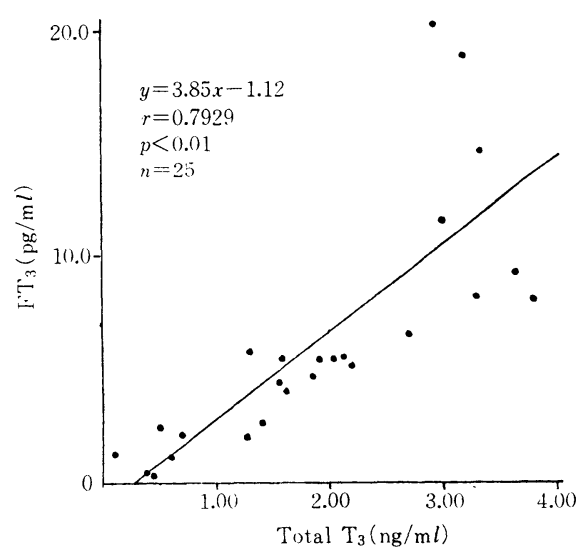

Fig. 6 Relation between $\mathrm{FT}_{3}$ and total $\mathrm{T}_{3}$.

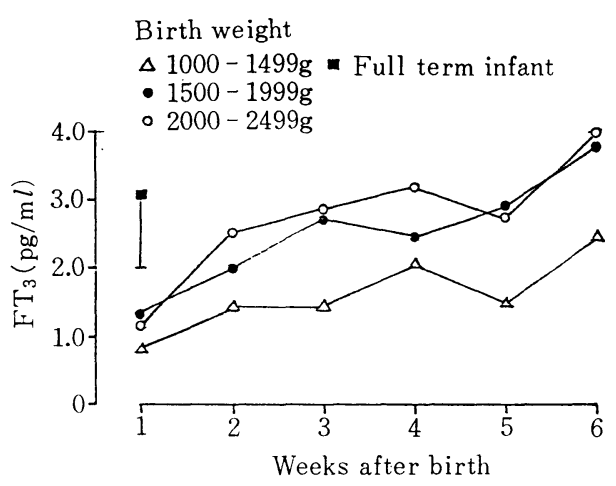

Fig. $7 \mathrm{FT}_{3}$ in premature infant.

\section{層の検討が待たれる。}

Euthyroid status にある乳児および 1ー15歳の小児の $\mathrm{FT}_{3}$ を測定した。小児期に拈ける $\mathrm{FT}_{3}$ は成人に比べ 有意に高值である。乳児期最も高く，加齢とともに漸 次低下していく傾向にある。Fisherら ${ }^{3)}$ は, total $\mathrm{T}_{3}$ と $\mathrm{T}_{3}$ talc uptake より free $\mathrm{T}_{3}$ index 算出し, free $\mathrm{T}_{3}$ index が小児期，加路令とともに低下していくと述べ

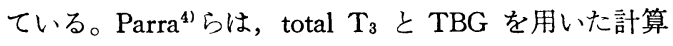
式より calcurated free $T_{3}$ として算出しているが，思 春期に TBG が低下することより, calcurated free $\mathrm{T}_{3}$ が思春期に上昇するとしている。今回のわれわれの結 果は，Fisher の報告とよく似ている。生理的意義は不 明とされるが， $\mathrm{FT}_{3}$ は小児期より成人期にむかって徐 々に低下していくのであろう。例数は少ないが，思春 期の上昇はないと思われる。

未熟児では生後しばらく total $\mathrm{T}_{3}$ が低值であること が知られている゙っ。出生体重の小さいものほどはなは だしい。FT については，成熟児の変化は報告されて いる゙が，未熟児についてはまだない。われわれの結 果では，成熟児に比べ，未熟児の $\mathrm{FT}_{3}$ がきわめて低 いことがわかる。とくに出生体重の小さいもの汪ど低 $\mathrm{FT}_{3}$ が遷延するといえる。この時期, TSH の上昇はな く, 原発性甲状腺機能低下症はないとされる。

\section{6. 結 語}

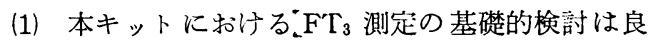
好な結果であった。

（2）甲状腺機能正常者群, 低下症群, 穴進症群は確 実に分離され，臨床的にも有用であると思われた。

（3）本キットでは TBG の影響を受けないと思われ た。

（4）低アルブミン血症では低值となる可能性が示さ れた。

(5) 小児期より成人にかけて $\mathrm{FT}_{3}$ 值は徐々に低下 していくことを認めた。

（6）未熟児の $\mathrm{FT}_{3}$ 值は成熟児に比べ低く，遷延す る傾向にある。

キットの提供をしていただいたアマシャム薬品㑣に 深謝いたします。

\section{文献}

1) Oppenheimer, J.H. : J. Clin. Invest., 42, 176982 (1963)

2) Amino, N.: Clin. Chem., 29, 321-25 (1983)

3) Fisher, D.A.: J. Clin. Endocrinol. Metab., 45, 191-98 (1977)

4) Parra, A.: Acta Endocrinologica, 93, 306-14 (1980)

5) Inomata, H. : "Neonatal Screening" (Naruse, $\mathrm{H}$. and Irie, M., eds.), pp.15-16, Excepta Medica, Amsterdam (1983)

6) Erenberg, A.: Pediatrics, 53, 211-16 (1974) 